\title{
Investigation the Relationship Between Body Mass Index and Mortality in COVID-19 Patients
}

\author{
Vücut Kitle İndeksi ile COViD-19 Hastalarının Mortalitesi Arasındaki ilişsinin \\ İrdelenmesi
}

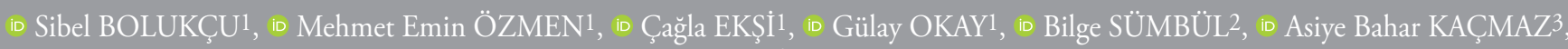

(D) Bülent DURDU1, id Yasemin AKKOYUNLU1, id Meliha MERIÇ KOÇ1

${ }^{1}$ Bezmialem Vakıf University Faculty of Medicine Training and Research Hospital, Department of Infectious Diseases and Clinical

Microbiology, İstanbul, Turkey

2Bezmialem Vakıf University Faculty of Medicine Training and Research Hospital, Department of Medical Microbiology, İstanbul, Turkey

${ }^{3}$ Bezmialem Vakıf University, Dragos Hospital, Clinic of Infectious Diseases and Clinical Microbiology, İstanbul, Turkey

\section{ABSTRACT}

Objective: Obesity might be a risk factor for patients with Coronavirus disease-19 (COVID-19). We aimed to investigate the association of the obesity with intensive care need and mortality caused by severe acute respiratory syndrome-CoV-2 (SARS-CoV-2) infection in this retrospective cohort.

Methods: Between March $11^{\text {th }}$ and May $1^{\text {st }}, 135$ patients, who were treated in our clinic, were enrolled in the study. Body mass index (BMIs) of the patients were grouped according as WHO criteria ( $<25 \mathrm{~kg} / \mathrm{m}^{2}$ : normal, $2530 \mathrm{~kg} / \mathrm{m}^{2}$ : overweight, $>30 \mathrm{~kg} / \mathrm{m}^{2}$ : obese).

Results: Of our patients, $34.1 \%(\mathrm{n}=46)$ were obese. Mean BMI of the mortality group was $31.2 \mathrm{~kg} / \mathrm{m}^{2}$ and was not different from that of the survivors $(\mathrm{p}=0.09)$, However, mean BMI of the patients, in whom intensive care was needed, was $31.2 \mathrm{~kg} / \mathrm{m}^{2}$ and higher than that of those intensive care was not needed $(\mathrm{p}=0.04)$. In subgroup analyses, obesity $\left(\mathrm{BMI}>30 \mathrm{~kg} / \mathrm{m}^{2}\right.$ ) was more common among mortality group versus survivors in males older than 60 years old $(\mathrm{p}=0.03)$.

Conclusion: Obesity with associated disorders are negative prognostic factors for COVID-19 and should be tackled as the end of the pandemic is obscure.

Keywords: COVID-19, obesity, Turkey

\section{ÖZ}

Amaç: Obezitenin, Koronavirüs hastalığı-19 (COVID-19) olguları için olumsuz bir risk faktörü olabileceği görülmektedir. $\mathrm{Bu}$ retrospektif kohortta, şiddetli akur solunum enfeksiyonu-CoV2'nin (SARS-CoV-2) sebep olduğu mortalite ve yoğun bakım ünitesinde takip edilme gereksinimi ile vücut kitle indeksi ilişkisini değerlendirmeyi amaçladık.

Yöntemler: 11 Mart-1 Mayıs 2020 tarihleri arasında kliniğimizde takip edilen 135 hasta çalışmaya dahil edildi. Hastaların VKİ değerleri Dünya Sağlık Örgütü’nün belirlediği değerlere göre gruplandırıldı $\left(<25 \mathrm{~kg} / \mathrm{m}^{2}=\right.$ normal, $25-30 \mathrm{~kg} / \mathrm{m}^{2}=$ kilolu ve $\left.30 \mathrm{~kg} / \mathrm{m}^{2}=\mathrm{obez}\right)$.

Bulgular: Buna göre olguların \%34,1 ( $\mathrm{n}=46)$ obezdi. Ölen olguların, vücut kitle indekslerinin ortanca değeri $31,2 \mathrm{~kg} / \mathrm{m} 2$ idi ve sağ kalan grupla benzerdi ( $p=0,09)$. Buna karşılık yoğun bakım ünitesinde takip edilen olguların, vücut kitle indeksilerinin ortanca değeri $31,2 \mathrm{~kg} / \mathrm{m}^{2}$ ve yoğun bakım ünitesinde takip edilmeyen olgulardan daha yüksekti $(\mathrm{p}=0,04)$. Alt grup analizlerinde $>60$ yaş erkek cinsiyet olanlarda sağ kalanlara göre ölenler obezdi (vücut kitle indeksi $\left.>30 \mathrm{~kg} / \mathrm{m}^{2}\right)(\mathrm{p}=0,03)$.

Sonuç: Obesite, kendisi ve beraberinde getirdiği hastalık yüküyle COVİD-19 gibi bir çok hastalıkta kötü prognostik faktördür. COVID-19 salgınının ne zaman sonlandırılacağı bilinmezken obezite gibi hastalığın seyri açısından olumsuz faktörlerle mücadele edilmesi gerektiği açıktır.

Anahtar Sözcükler: COVİD-19, obezite, Türkiye 


\section{Introduction}

Since severe acute respiratory syndrome-coronavirus-2 (SARSCoV-2) first appeared in Wuhan, China, 7,039,918 people around the world have been diagnosed with COVID-19 and 404,396 of them died [World Health Organization (WHO); accessed on $9^{\text {th }}$ June 2020]. Again, according to WHO data, the first case in Turkey was confirmed on $11^{\text {th }}$ March 2020, a total of 171,121 cases were diagnosed which corresponds to 2029 cases per 1 million population and 56 deaths per 1 million population.

Studies during the early period of the pandemic suggested that the disease had a more severe course in the elderly population, men, and those with comorbidities (1). Abdominal obesity is known to cause abnormal synthesis of adipokines and cytokines such as tumor necrosis alpha (TNF-alpha) and interferon, causing a chronic low-level inflammation that can damage the lung parenchyma and bronchi $(2,3)$. Obesity appears to be a risk factor for COVID-19 cases.

The aim of this retrospective cohort study was to evaluate the relationship between the mortality caused by SARS-CoV-2 and the need to be followed in the intensive care unit (ICU) and body mass index (BMI).

\section{Method}

This retrospective cohort study was conducted in a single center. Starting from the first case on $11^{\text {th }}$ March, 2020, all cases followed at the Infectious Diseases Clinic of Bezmialem Vakıf University Faculty of Medicine until ${ }^{\text {st }}$ May 2020 were included. The diagnosis was made taking into account the updates of the Ministry of Health's National COVID-19 Guide. The microbiological examination was performed by reverse transcription-polumerose chair reaction (RT-PCR) analysis of nasopharyngeal swab samples. From the database gender, age, BMI, RT-PCR result of nasopharyngeal swap samples, and follow-up and survival data in the ICU were analyzed. BMI values were grouped according to WHO criteria $\left(<25 \mathrm{~kg} / \mathrm{m}^{2}=\right.$ normal, $25-30 \mathrm{~kg} / \mathrm{m}^{2}=$ overweight, $\geq 30 \mathrm{~kg} / \mathrm{m}^{2}=$ obese) (4).

\section{Statistical Analysis}

Chi-square test and Fisher's exact test were used to analyze the difference between the percentages of categorical data. The significance of the difference between the mean ages of the dead and survived patients was evaluated with the Student t-test and the significance of the difference between the medians of BMI was analyzed using the Mann-Whitney U test. Whether the BMI groups showed a trend in survival and follow-up in the ICU was analyzed with the chi-square trend and post-hoc $\mathrm{z}$ test.

\section{Results}

This study included 135 patients. Among them $57.8 \%$ ( $\mathrm{n}=78)$ were males and the mean age was $52.5 \pm 16.1$ years. The median BMI value was 27.7 (interquartile range: $24.1-31.2$ ). The highest BMI was $56 \mathrm{~kg} / \mathrm{m}^{2}$. In $39.3 \%(\mathrm{n}=53)$ of the cases RT-PCR was positive in a nasopharyngeal swap and/or there were radiological findings + clinical features were compatible; in other cases, radiological and clinical findings were compatible. Fifteen cases were followed in ICU and 13 cases died (Table 1).

According to WHO classification $27.4 \%(\mathrm{n}=37)$ were $<25 \mathrm{~kg} /$ $\mathrm{m}^{2}, 38.5 \%(\mathrm{n}=52)$ were between $25-30 \mathrm{~kg} / \mathrm{m}^{2}$ and $34.1 \%(\mathrm{n}=46)$ were $>30 \mathrm{~kg} / \mathrm{m}^{2}$. Obesity $\left(\mathrm{BMI}>30 \mathrm{~kg} / \mathrm{m}^{2}\right)$ was more common among females $(\mathrm{n}=28,49.1 \%)(\mathrm{p}=0.002)$.

The median BMI value of cases followed in ICU $\left(31.2 \mathrm{~kg} / \mathrm{m}^{2}\right)$ was higher than cases who were not followed in ICU $(\mathrm{p}=0.04)$. In addition, their mean age was $(61.6 \pm 14.9)$ higher than cases followed at a ward $(\mathrm{p}=0.02)$. Comparison of the BMI groups according to follow-up in the ICU revealed that obese patients were followed in the ICU more than the other two groups $(\mathrm{p}=0.03)$.

The median BMI value of dead cases was $\left(31.2 \mathrm{~kg} / \mathrm{m}^{2}\right)$ similar to the BMI value of survivors $(\mathrm{p}=0.09)$. The mean age of dead patients $(62.9 \pm 14.5)$ was higher than survivors $(\mathrm{p}=0.01)$.

Subgroup analyses of dead cases revealed that the mean BMI value of females $\geq 60$ years of age was similar to survivors $(\mathrm{p}=0.97)$. Among males in this age group, died cases were more frequently obese $\left(B M I>30 \mathrm{~kg} / \mathrm{m}^{2}\right)$ than survivors $(\mathrm{p}=0.03)$ (Table 2). In both sexes, no mortality was observed in normal weight, overweight, and obese groups. In females, mortality was in cases above 50 years of age.

Table 1. Features of dead and survived patients

$\begin{array}{ll}\begin{array}{l}\text { Survived } \\ \text { patients }\end{array} & \text { Dead patients } \\ (n=122) & (n=13)\end{array}$

\begin{tabular}{|c|c|c|c|}
\hline \multicolumn{4}{|l|}{ Sex $(n ; \%)$} \\
\hline Female & $53 ; 93$ & $4 ; 7$ & \\
\hline Male & $69 ; 88.5$ & $9 ; 11.5$ & 0.0 \\
\hline Mean age \pm SD & $51.4 \pm 16.01$ & $62.9 \pm 14.5$ & $0.01 *$ \\
\hline Median BMI (IQR) & $27.6(24.1-30.8)$ & $31.2(25.5-34.3)$ & 0.09 \\
\hline \multicolumn{4}{|l|}{ BMI groups (n;\%) } \\
\hline Normal & $35 ; 94.6$ & $2 ; 5.4$ & \\
\hline Overweight & $48 ; 92.3$ & $4 ; 7.7$ & 0.1 \\
\hline Obese & $39 ; 84.8$ & $7 ; 15.2$ & \\
\hline $\begin{array}{l}\text { RT-PCR positivity } \\
n ; \%\end{array}$ & $41 ; 77.4$ & $12 ; 22.6$ & $0.0001 *$ \\
\hline ICU follow up n;\% & $3 ; 20$ & $12 ; 80$ & $0.0001 *$ \\
\hline
\end{tabular}

\section{Discussion}

COVID-19 continues to be an important health problem in Turkey as well as all over the World. Particular attention should be paid to elderly people with co-morbidities due to severity of illness, need for ICU, and the high risk of death in this group. 


\begin{tabular}{|c|c|c|c|c|}
\hline & Normal & Overweight & Obese & $\mathrm{p}$ \\
\hline \multicolumn{5}{|c|}{ Males, age groups } \\
\hline$<30$ & NA & NA & NA & \\
\hline $30-40$ & 0 & $1 ; 7.7$ & 0 & \\
\hline $40-50$ & 0 & $1 ; 20$ & $1 ; 20$ & 0.6 \\
\hline $50-60$ & $1 ; 20$ & 0 & $1 ; 20$ & 1 \\
\hline$>60$ & 0 & $2 ; 20$ & $2 ; 50 *$ & 0.03 \\
\hline \multicolumn{5}{|c|}{ Females, age groups } \\
\hline$<30$ & NA & NA & NA & \\
\hline $30-40$ & NA & NA & NA & \\
\hline $40-50$ & NA & NA & NA & \\
\hline $50-60$ & NA & 0 & $1 ; 14,3$ & 1 \\
\hline$>60$ & $1 ; 20$ & 0 & $2 ; 15.4$ & 0.97 \\
\hline
\end{tabular}

Obesity is known to be associated with many comorbid conditions. The aim of our study was to examine the effect of obesity in terms of survival and follow-up in ICU, considering age groups and gender.

There is an obesity epidemic all over the World. Obesity is also a growing health problem in Turkey. In the recent national health statistics data, it has been emphasized that the rate of obese people in both genders has increased (females 24.8\% males 17.3\%) (accessed from http://www.tuik.gov.tr/PreHaberBultenleri. do?id=33661). In 2017-2018 the prevalence of obesity in the USA was $42.4 \%$ and among them, $9.2 \%$ had BMI $>40 \mathrm{~kg} / \mathrm{m}^{2}$ (accessed from https:/www.cdc.gov/obesity/data/adult.html). Obesity has negative consequences on the lives of individuals and communities. It is associated with many comorbidities (5). Obesity is accompanied by several COVID-19 risk factors (e.g diabetes mellitus, hypertension) (6). Obesity was observed to be associated with severe disease during the H1N1 epidemic (7). Experiences gained in the H1N1 epidemic can also provide insight into COVID-19 cases. Given the growing COVID-19 outbreak in countries with a high prevalence of obesity such as the USA, UK, and Mexico, clarification of the relationship between obesity and COVID-19 severity seems to be very important (8-11). A study conducted in France found that after standardization according to age and gender, the prevalence of obesity in severe COVID-19 patients was 1.35 times higher than the general French population (8). In contrast, obesity was not associated with mortality in the Chinese case series (1). However, although the rate of diseases associated with obesity such as diabetes, hypertension, and coronary artery disease was high in some case series reported from China, obesity was not reported among the underlying conditions $(12,13)$. We couldn't find a study from Turkey about the course of obesity in COVID-19 cases in our literature scan. The median BMI of the patients who died in our study was not different from the survivors.

In addition, according to the WHO classification, mortality rates in the obese group were not higher than in the surviving group. Simonnet et al. (14) demonstrated a relationship between obesity and disease severity in patients followed with a diagnosis of COVID-19 (14). In a study examining the recent national data in Mexico, higher mortality rates $(13.5 \%$ vs $9.4 \%$ ), hospitalization, and pneumonia were observed in obese COVID-19 cases. In addition, they noted that obese patients were followed in the ICU at a higher rate (5.0\% versus 3.3\%) and needed mechanical ventilation at a higher rate $(5.2 \%$ versus $3.3 \%$ ) (10). Similarly, another study demonstrated that the rates of being followed in the ICU in the presence of obesity were 1.89 times higher (8). In our study, the mean BMI of patients followed in the ICU was higher than those followed in the ward and the rate of obesity was higher in patients followed in ICU. A previous study demonstrated that mortality increased in the presence of obesity in patients $<40$ years old. In the same study obesity, early-onset diabetes mellitus, and accompanying comorbidities also increased mortality (10). Unlike this, we did not observe the effect of obesity on mortality in young patients.

In a study examining New York City data, BMI $>30 \mathrm{~kg} / \mathrm{m}^{2}$ in COVID-19 cases $<60$ years of age was a risk factor for follow-up in the ICU (9). In the subgroup analysis of our study, mortality in $>60$ years of age males was higher than other age groups and females. This result suggested that factors affecting mortality in young patients should be evaluated.

\section{Conclusion}

In conclusion, the obesity epidemic in many countries, including the USA and Turkey, should cause worry as much as the COVID-19 pandemic. Obesity, by itself and with accompanying diseases, is a poor prognostic factor for many diseases including COVID-19. Therefore, it is clear that short and long-term national and international strategies should be determined in the fight against obesity.

\section{Ethics}

Ethics Committee Approval: Bezmialem Vakıf University Clinical Research Ethics Committee (no: 71306642-050.05.04-)

Peer-review: Externally peer reviewed.

\section{Authorship Contributions}

Surgical and Medical Practices: A.B.K., Concept: S.B., Design: S.B., Data Collection or Processing: M.E.Ö., Ç.E., Analysis or Interpretation: S.B., Literature Search: S.B., G.O., A.B.K., B.D., Y.A., M.M.K., Writing: S.B., M.E.Ö., Ç.E., G.O., B.S., A.B.K., B.D., Y.A., M.M.K.

Conflict of Interest: No conflict of interest was declared by the authors.

Financial Disclosure: This work was supported by Gilead Sciences.

\section{References}

1. Guan W-j, Ni Z-y, Hu Y, Liang W-h, Ou C-q, He J-x, et al. Clinical Characteristics of Coronavirus Disease 2019 in China. 2020;382:1708-20. 
2. Huttunen R, Syrjänen J. Obesity and the risk and outcome of infection. International journal of obesity. 2013;37:333-40.

3. Zhang X, Zheng J, Zhang L, Liu Y, Chen GP, Wang L, et al, editors. Systemic inflammation mediates the detrimental effects of obesity on asthma control. Allergy \& Asthma Proceedings; 2018.

4. World Health Organization. Report of the WHO-China Joint Mission on Coronavirus Disease 2019 (COVID-19). Geneva: World Health Organization. 16-24 February 2020.

5. Visscher TL, Lakerveld J, Olsen N, Küpers L, Ramalho S, Keaver L, et al. Perceived Health Status: Is Obesity Perceived as a Risk Factor and Disease? Obesity facts. 2017; 10:52-60.

6. Ryan DH, Ravussin E, Heymsfield S. COVID 19 and the patient with obesity-the editors speak out. J Obesity. 2020.

7. Lee EH, Wu C, Lee EU, Stoute A, Hanson H, Cook HA, et al. Fatalities associated with the $2009 \mathrm{H} 1 \mathrm{~N} 1$ influenza A virus in New York city. Clin Infect Dis 2010;50:1498-504.

8. Caussy C, Pattou F, Wallet F, Simon C, Chalopin S, Telliam C, et al. Prevalence of obesity among adult inpatients with COVID-19 in France. Lancet Diabetes Endocrinol 2020;8:562-4.

9. Lighter J, Phillips M, Hochman S, Sterling S, Johnson D, Francois $\mathrm{F}$, et al. Obesity in patients younger than 60 years is a risk factor for Covid-19 hospital admission. Clin Infect Dis 2020.
10. Bello-Chavolla OY, Bahena-López JP, Antonio-Villa NE, VargasVázquez A, González-Díaz A, Márquez-Salinas A, et al. Predicting Mortality Due to SARS-CoV-2: A Mechanistic Score Relating Obesity and Diabetes to COVID-19 Outcomes in Mexico. J Clin Endocrinol Metab 2020;105.

11. Docherty AB, Harrison EM, Green CA, Hardwick HE, Pius R, Norman L, et al. Features of 16,749 hospitalised UK patients with COVID-19 using the ISARIC WHO Clinical Characterisation Protocol. J medRxiv 2020:2020.04.23.20076042.

12. Du Y, Tu L, Zhu P, Mu M, Wang R, Yang P, et al. Clinical Features of 85 Fatal Cases of COVID-19 from Wuhan. A Retrospective Observational Study 2020;201(11):1372-9.

13. Zhang G, Hu C, Luo L, Fang F, Chen Y, Li J, et al. Clinical features and short-term outcomes of 221 patients with COVID-19 in Wuhan, China. J Clin Virol 2020;127:104364.

14. Simonnet A, Chetboun M, Poissy J, Raverdy V, Noulette J, Duhamel A, et al. High Prevalence of Obesity in Severe Acute Respiratory Syndrome Coronavirus-2 (SARS-CoV-2) Requiring Invasive Mechanical Ventilation.n/a(n/a). doi: 10.1002/oby.22831. 